Article

\title{
Structural Elucidation of Malonylcommunol and 6ß-Hydroxy-trans-communic Acid, Two Undescribed Diterpenes from Salvia cinnabarina. First Examples of Labdane Diterpenoids from a Mexican Salvia Species
}

\author{
Celia Bustos-Brito $₫$, Antonio Nieto-Camacho $₫$, Simón Hernandez-Ortega $₫$, José Rivera-Chávez, \\ Leovigildo Quijano *(i) and Baldomero Esquivel * \\ Instituto de Química, Universidad Nacional Autónoma de México, Circuito Exterior, Ciudad Universitaria, \\ Mexico City 04510, Mexico; celia.bustos@iquimica.unam.mx (C.B.-B.); anieto@unam.mx (A.N.-C.); \\ simonho@unam.mx (S.H.-O.); jrivera@iquimica.unam.mx (J.R.-C.) \\ * Correspondence: quijano@unam.mx (L.Q.); baldo@unam.mx (B.E.); Tel.: +52-55-5622-4411 (L.Q.); \\ $+52-55-5622-4448$ (B.E.)
}

Received: 29 February 2020; Accepted: 8 April 2020; Published: 15 April 2020

\begin{abstract}
The aerial parts of Salvia cinnabarina afforded two undescribed labdane diterpenoids 1 and 2 (malonylcommunol and 6 $\beta$-hydroxy-trans-communic acid) along with two known labdane diterpenoids, trans-communic acid (3) and trans-communol (4). Additionally, seven known metabolites were also isolated; two isopimarane diterpenoids $\mathbf{5}$ and $\mathbf{6}$, two sesquiterpenoids identified as $\beta$-eudesmol (7) and cryptomeridiol (8), and three aromatic compounds identified as phthalic acid (9), a mixture of tyrosol fatty acid esters (10) and the flavone salvigenine (11). While compounds compounds 1-3 showed significant inhibition of yeast $\alpha$-glucosidase, compounds 2,3 and $\mathbf{7}$ had no anti-inflammatory activity in the edema model induced by TPA. This paper is not only the first report on a wild population of Salvia cinnabarina, but also of the presence of labdane-type diterpenoids in a Mexican Salvia sp.
\end{abstract}

Keywords: Salvia cinnabarina; labdane diterpenoid; $\alpha$-glucosidase

\section{Introduction}

Salvia L. is the largest genus of Lamiaceae family of plants, with over 1000 species distributed worldwide [1]. The name of the genus derives from the Latin verb "salvare" which means to heal. This is very likely due to the fact that some of these plant species (Salvia divinorum Epling and Játiva, S. milthiorrhiza Bunge and S. officinalis L. [2]) have been used since ancient times to treat several ailments, and are important medicinal herbs in both traditional and modern medicine. Mexico is one of the most important areas of diversification of the genus in the world, with over 319 species, representing ca. $32 \%$ of the total, although this number is continuously increasing due to the discovery of new species [3]. Several Salvia species are utilized in different regions of the country for treatment of various ailments, with some well recognized as part of several medicinal plant complexes [2].

Salvia cinnabarina M. Martens and Galeotti (Section Incarnatae), a plant originating from Mexico, is used for the treatment of colic and rheumatism in the Mexican state of Chiapas. Antibacterial and spasmolytic activities have been also described for this species [4].

Previous studies on S. cinnabarina include the analysis of volatile organic compounds [5], and the essential oil obtained from fresh aerial parts of the plant by steam distillation [6], as well as phytochemical analysis of the leaf exudate leading to the isolation of a 3,4-seco-isopimarane diterpenoid whose structure and relative stereochemistry was established as 3,4-seco-isopimara-4(18),7,15-trien-3-oic acid (12) by 
spectroscopic and X-ray diffraction analysis [7,8]. Compound $\mathbf{1 2}$ has been tested in several in vitro and in vivo models and exhibits a wide array of biological activities, such as antispasmodic in the isolated guinea-pig ileum model, inhibition of urinary bladder contractility in rats [9] and intestinal motility in mice [10]. Hypotensive activity in a rat model [11], along with anxiolytic and anti-depressive effects in the elevated plus-maze and the forced swimming tests in mice have also been described [12]. Compound 12 showed antimutagenic activity in the Ames test on Salmonella typhimurium and Escherichia coli [13] and also had an anticlastogenic effect in human lymphocytes of its sodium salt [14]. It should be noted that, up to now, all the studies on S. cinnabarina, have been carried out solely on cultivated material from different Botanical Gardens.

Continuing with our systematic study of the genus Salvia in Mexico, and ongoing investigation for biological activity diterpenes of chemosystematic importance [15], we report herein the first study on a wild population of S. cinnabarina collected in the State of Puebla (Mexico). Several diterpenoids of the labdane (1-4) and isopimarane (5-6) skeletons were isolated, as well as two eudesmane-type sesquiterpenoids (7-8), phtalic acid (9), tyrosol derivatives (10) and the flavone salvigenin (11). Compounds 1-2 proved to be undescribed labdane-type diterpenoids related to trans-communic acid (3) and trans-communol (4), also isolated from this plant, and their structures were established as malonylcommunol (1) and 6 $\beta$-hydroxy-trans-communic acid (2). While compounds 1-3 showed significant inhibition of yeast $\alpha$-glucosidase, compounds 2,3 and 7 showed no anti-inflammatory activity in the edema model induced by TPA.

\section{Results and Discussion}

The aerial parts of Salvia cinnabarina afforded 11 compounds (Figure 1) after extensive chromatographic separation and purification.
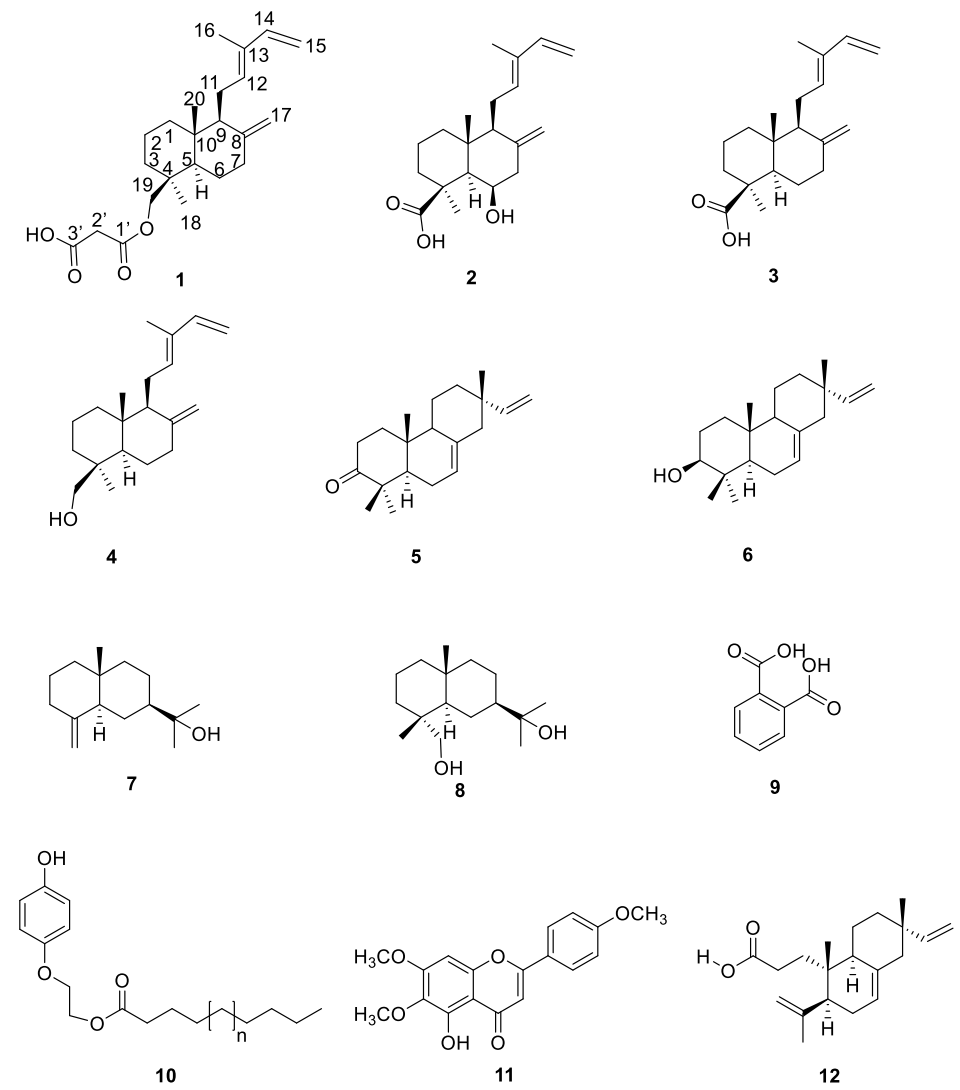

Figure 1. Chemical structures of 1-12. 
Compound 1 was isolated as a solid, m.p. $=85-90{ }^{\circ} \mathrm{C}$. The mass spectrum obtained by DART technique allowed to establish the chemical formula as $\mathrm{C}_{23} \mathrm{H}_{34} \mathrm{O}_{4}$ with seven degrees of unsaturation. The ${ }^{13} \mathrm{C}$ NMR spectrum (Table 1) of $\mathbf{1}$, corroborated the presence of 23 carbon atoms, which, according to the HSQC spectrum correspond to ten methylenes (two $\mathrm{sp}^{2}$ and eight $\mathrm{sp}^{3}$ ), four methines (two $\mathrm{sp}^{2}$ and two $\mathrm{sp}^{3}$ ), two quaternary carbons, four nonprotonated carbons and three methyl groups. In the ${ }^{13} \mathrm{C}$ NMR spectrum of $\mathbf{1}$ (Table 1), signals for an exocyclic methylene, such as the one present at C-8:C-17 of trans-communic acid (3) [16] and trans-communol (4) [16] are observed at $\delta 147.7$ (C) and 108.2 $\left(\mathrm{CH}_{2}\right) \mathrm{ppm}$. Observed signals for carbon atoms of a terminal vinyl group at $\delta 141.7(\mathrm{CH})$ and 110.1 $\left(\mathrm{CH}_{2}\right)$, together with those observed at $133.8(\mathrm{CH}), 133.7(\mathrm{C}), 23.3\left(\mathrm{CH}_{2}\right)$ and $12.0\left(\mathrm{CH}_{3}\right)$, suggested that compound 1 has a side chain identical to the one present in diterpenes 3 and 4 . Therefore, the signals at $\delta 141.7$ and 110.1 were assigned to $C-14$ and $C-15$ and those at 133.8, 133.7, 23.3 and $12.0 \mathrm{ppm}$, to $C-12$, C-13, C-11 and C-16, respectively. The chemical shifts of C-14 (141.7) and C-16 (12.0) confirmed the configuration of the C-12:C-13 double bond as $E$ (trans). The chemical shifts of these carbon atoms are very sensitive to the double bond configuration, being observed at approximately 130 and $20 \mathrm{ppm}$ in the case of a Z (cis) configuration [17,18].

Table 1. NMR Data $\left({ }^{1} \mathrm{H} 700 \mathrm{MHz}\right.$ and $\left.{ }^{13} \mathrm{C} 175 \mathrm{MHz}, \mathrm{CDCl}_{3}\right)$ of 1 .

\begin{tabular}{|c|c|c|c|c|}
\hline Position & $\delta_{C}$ & Type $^{a}$ & $\delta_{\mathrm{H}}(J$ In $\mathrm{Hz})$ & НМВС \\
\hline $1 \mathrm{a}$ & 39.0 & $\mathrm{CH}_{2}$ & 1.83, brd $(12.5)$ & $2,3,5,20$ \\
\hline $1 b$ & & & $1.13, \operatorname{td}(12.5,5.4)$ & $2,3,5,10,20$ \\
\hline 2 & 19.0 & $\mathrm{CH}_{2}$ & $1.52, \mathrm{~m}$ & $1,3,4$ \\
\hline $3 a$ & 36.2 & $\mathrm{CH}_{2}$ & 1.73, brd $(12.8)$ & $1,2,4,5,18,19$ \\
\hline $3 b$ & & & $1.04, \mathrm{td}(12.8,5.3)$ & $1,2,4,18,19$ \\
\hline 4 & 37.6 & $\mathrm{C}$ & & \\
\hline 5 & 56.2 & $\mathrm{CH}$ & 1.30, brd (12.5) & $1,6,7,18,19,20$ \\
\hline $6 a$ & 24.3 & $\mathrm{CH}_{2}$ & $1.83, \mathrm{~m}$ & 5,8 \\
\hline $6 b$ & & & $1.34, \mathrm{dq}(12.5,3.9)$ & 5,7 \\
\hline $7 a$ & 38.3 & $\mathrm{CH}_{2}$ & $2.39, \mathrm{~m}$ & $5,6,9,17$ \\
\hline $7 \mathrm{~b}$ & & & $1.97, \operatorname{td}(12.5,4.6)$ & $5,6,8,17$ \\
\hline 8 & 147.7 & $\mathrm{C}$ & & \\
\hline 9 & 57.2 & $\mathrm{CH}$ & 1.75, brd $(13.0)$ & $8,11,12,17,20$ \\
\hline 10 & 39.5 & C & & \\
\hline $11 \mathrm{a}$ & 23.3 & $\mathrm{CH}_{2}$ & $2.36, \mathrm{~m}$ & $8,9,12,13,14{ }^{*} 17^{*}$ \\
\hline $11 b$ & & & $2.14, \mathrm{~m}$ & $8,9,12,13,14$ * \\
\hline 12 & 133.8 & $\mathrm{CH}$ & 5.39, brt $(6.2)$ & $9,11,14,16$ \\
\hline 13 & 133.7 & $\mathrm{C}$ & & \\
\hline 14 & 141.7 & $\mathrm{CH}$ & $6.32, \mathrm{dd}(17.4,10.7)$ & $12,13,16$ \\
\hline $15 a$ & 110.1 & $\mathrm{CH}_{2}$ & $5.04, \mathrm{~d}(17.4)$ & $12, * 13,14$ \\
\hline $15 b$ & & & $4.88, \mathrm{~d}(10.7)$ & $12, * 13,14$ \\
\hline 16 & 12.0 & $\mathrm{CH}_{3}$ & $1.74, \mathrm{~s}$ & $12,13,14$ \\
\hline $17 \mathrm{a}$ & 108.2 & $\mathrm{CH}_{2}$ & $4.82, \mathrm{brs}$ & $6, * 7,8$ \\
\hline $17 \mathrm{~b}$ & & & $4.47, \mathrm{brs}$ & $6, * 7,8,9$ \\
\hline 18 & 27.6 & $\mathrm{CH}_{3}$ & $0.97, \mathrm{~s}$ & $3,5,19$ \\
\hline $19 a$ & 68.5 & $\mathrm{CH}_{2}$ & $4.38, \mathrm{~d}(10.9)$ & $3,5,3^{\prime}, 18$ \\
\hline $19 b$ & & & $3.95, \mathrm{~d}(10.9)$ & $3,5,3^{\prime}, 18$ \\
\hline 20 & 15.4 & $\mathrm{CH}_{3}$ & $0.72, \mathrm{~s}$ & $1,5,9,10$ \\
\hline $1^{\prime}$ & 169.6 & $\mathrm{C}^{J}$ & & \\
\hline $2^{\prime}$ & 40.7 & $\mathrm{CH}_{2}$ & 3.41 , brs & $1^{\prime}, 3^{\prime}, 19$ \\
\hline $3^{\prime}$ & 168.3 & $\mathrm{C}$ & & \\
\hline
\end{tabular}

The ${ }^{1} \mathrm{H}$ NMR spectrum of $\mathbf{1}$ (Table 1), was also similar to that of trans-communol (4), with signals for the terminal vinyl group being observed at $\delta 6.32(1 \mathrm{H}, \mathrm{dd}, J=17.3$ and $10.7 \mathrm{~Hz}, \mathrm{H}-14), 5.04(1 \mathrm{H}$, $\mathrm{d}, J=17.4 \mathrm{~Hz}, \mathrm{H}-15$ trans $)$ and $4.88(1 \mathrm{H}, \mathrm{d}, J=10.7 \mathrm{~Hz}, \mathrm{H}-15 \mathrm{~b}$ cis $)$. A triplet at $5.39 \mathrm{ppm}(J=6.2 \mathrm{~Hz})$ was assigned to $\mathrm{H}-12$ and a singlet for three hydrogen atoms at $1.74 \mathrm{ppm}$ to the $\mathrm{C}-16$ methyl group. 
Characteristic signals for the hydrogen atoms of the exocyclic methylene at $\mathrm{C}-8(\mathrm{H}-17)$ were also observed in the ${ }^{1} \mathrm{H}$ NMR spectrum of $\mathbf{1}$ as broad singlets at 4.82 and $4.47 \mathrm{ppm}$.

A relevant signal in the ${ }^{1} \mathrm{H}$ NMR spectrum for the structural assignment of diterpene 1 , was a broad singlet integrating for two hydrogen atoms at $3.41 \mathrm{ppm}$, that disappears upon addition of $\mathrm{D}_{2} \mathrm{O}$. This signal correlated in the HMBC spectrum (Table 1) with two carbonyl signals located at 169.6, 168.3 and a methylene signal at $68.5 \mathrm{ppm}$. The first two signals are assigned to the carbonyls of an acid and an ester, respectively, and the third to a methylene whose hydrogen atoms are observed in the ${ }^{1} \mathrm{H} \mathrm{NMR}$ spectrum, as an AB system at 4.38 and 3.95 ppm $(J=10.9)$. The IR spectrum of $\mathbf{1}$ is congruent with the existence of a carboxylic acid and an ester group in this compound, since a broad band centered at approximately $3000 \mathrm{~cm}^{-1}$ a carbonyl band in $1721 \mathrm{~cm}^{-1}$ (characteristic of a carboxylic acid) and a carbonyl ester band at $1736 \mathrm{~cm}^{-1}$ were observed. The above discussion, and the similarity between the NMR spectra of trans-communol (4) and those of $\mathbf{1}$, allows us to conclude the presence of a malonic acid ester at position C-19 in compound $\mathbf{1}$, which was named malonylcommunol (1). The exchange of the protons of the methylene group at $3.41 \mathrm{ppm}$ of the malonyl group upon addition of $\mathrm{D}_{2} \mathrm{O}$ could be explained by the enolization of the 1,3 dicarbonyl moiety [19]. The NOESY spectrum of 1 confirms the structure and relative stereochemistry proposed for this unpublished diterpene isolated from S. cinnabarina, on account of observation of expected interactions, illustrated in Figure 2. A malonate ester of a labdane diterpenoid from Calceolaria corymbosa Ruiz and Pav (Scrophulariaceae), with the same connectivity as malonylcommunol (1), was isolated in 1993 by Garbarino and Molinari [17]. However, the double bond has a Z configuration between carbons C-12 and C-13 in the diterpene from C. corymbosa. According to the authors it belongs to the ent-labdane series and therefore is a stereoisomer of $\mathbf{1}$. To establish the absolute configuration of $\mathbf{1}$, its experimental ECD spectrum (Figure 3) was recorded and compared with those registered for compounds 3 and 4 (Figure 3), whose stereochemistry has been previously determined [16]. The ECD spectrum of $\mathbf{1}$ displayed a negative Cotton effect at $203 \mathrm{~nm}$ and a positive one at $226 \mathrm{~nm}$ and was in good agreement with those of 3 and 4 . Additionally, ECD calculations for the $4 S 5 R 9 S 10 R$ diastereomers of $\mathbf{3}$ and $\mathbf{4}$ and their enantiomers (4R5S9R10S) were performed, interestingly, the curves matched the calculated for diasteroisomers 4S5R9S10R (Figure 3). Thus, the absolute configuration of compound 1 was determined to be $4 S 5 R 9 S 10 R$.

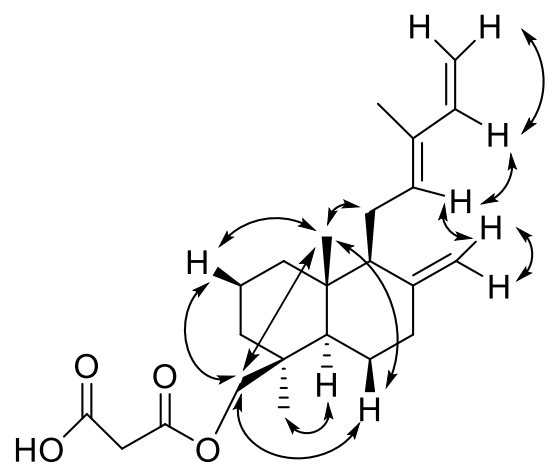

Figure 2. Key NOESY interactions observed for compound 1. 


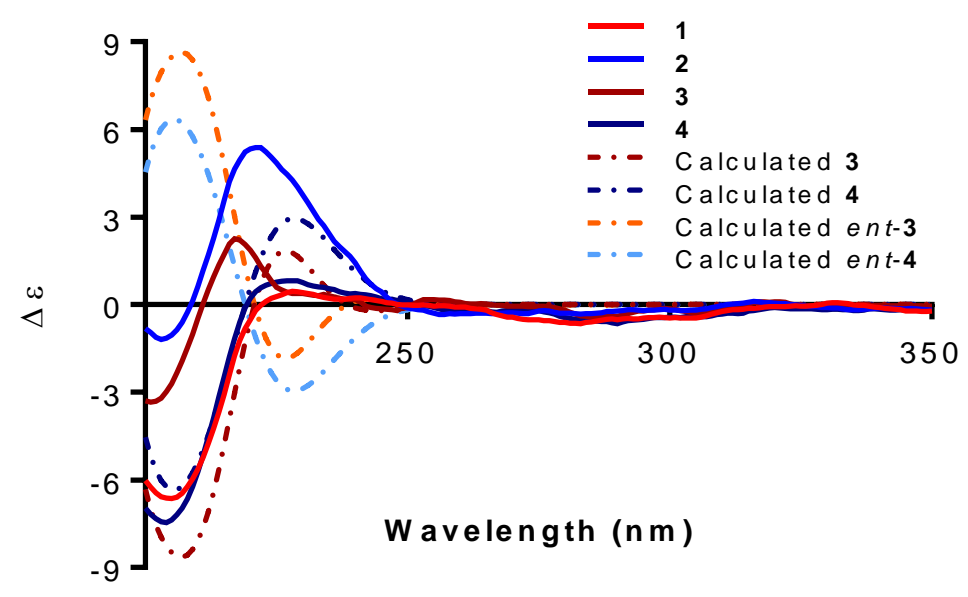

Figure 3. Experimental ECD spectra for compounds 1-4. Calculated ECD spectra for 3 (burgundy dashed line), ent-3 (orange dashed line), compound 4 (navy dashed line) and ent-4 (sky-blue dashed line). A negative shift of $-20 \mathrm{~nm}$ was required to match the spectra.

Diterpene malonates are relatively common, several examples and even products in which both acidic functions of malonic acid are esterified with diterpenic alcohols have been described [20-27]. Compound 1 is an unpublished malonate diterpenoid and the first described in any Salvia species.

The second unreported labdane diterpenoid obtained from the dichloromethane extract of S. cinnabarina was isolated as a white solid, m.p. $170-173^{\circ} \mathrm{C}$, whose molecular formula established by mass spectrometry as $\mathrm{C}_{20} \mathrm{H}_{30} \mathrm{O}_{3}$. These data, in addition to the ${ }^{1} \mathrm{H}$ and ${ }^{13} \mathrm{C}$ NMR data (Table 2), allow us to propose structure 2 for this undescribed diterpene. The ${ }^{1} \mathrm{H}$ NMR spectrum exhibits similar signals to those observed for trans-communic acid (3). The main difference in the spectrum of 2 is the presence of a wide quartet-like signal centered at $4.52(\mathrm{~J}=2.1 \mathrm{~Hz})$ ppm that is assigned to a hydrogen atom geminal to a hydroxyl group which interacts with a broad singlet at $1.46 \mathrm{ppm}$ and with the signals of a methylene at 2.34 and $2.50 \mathrm{ppm}$ according to the correlations observed in its COSY spectrum. The signal at $1.46 \mathrm{ppm}$ correlates in the HSQC spectrum (Table 2) with a $\mathrm{sp}^{3}$ methine carbon observed at $57.5 \mathrm{ppm}$ in the ${ }^{13} \mathrm{C}$ NMR spectrum of $\mathbf{2}$ which is assigned by its chemical shift to C-5. These facts allow locating the hydroxyl group at C-6 position and the coupling constants of the observed signal for its geminal hydrogen atom $(\mathrm{H}-6)$ indicate a $\beta$-axial orientation for the $\mathrm{OH}$ group. The analysis of the NOESY spectrum confirms the structure and relative stereochemistry assigned to this product, as the expected correlations are observed and the most relevant being those of $\mathrm{H}-5$ with $\mathrm{H}-6$ and the C-18 methyl (Figure 4). In its IR spectrum characteristic bands for hydroxy groups in 3684, 3590 and $3531 \mathrm{~cm}^{-1}$ were observed, as well as a broad band centered at approximately $3000 \mathrm{~cm}^{-1}$ attributed to the hydroxy group of a carboxylic acid, whose carbonyl group is observed at $1725 \mathrm{~cm}^{-1}$. In the spectrum, signals attributable to double bonds at 1647 and $1605 \mathrm{~cm}^{-1}$ were also observed. Based on the previous discussion, product 2 should be named $6 \beta$-hydroxy-trans-communic acid, which has not been previously described. The absolute configuration of $6 \beta$-hydroxy-trans-communic acid (2) was established to be 4 S5R6R9S10R by comparison of its experimental ECD curve with those recorded for 1, 3 and 4, which coexist in this population of S. cinnabarina. In addition, in 1965, a diterpene called zanzibaric acid was isolated from Trachylobium verrucosum Engl., whose structure and absolute configuration were established by spectroscopic means, as well as chemical correlation with a derivative of neo-abietic acid, establishing that zanzibaric acid is an ent-labdane [28]. Treatment of the zanzibaric acid methyl ester with $\mathrm{NaOH}$ in ethanol gave a product called 6-deacetylzanzibaric acid, whose connectivity is similar to that found for product 2. However, comparison of m.p. and the specific rotation indicates that they are diastereoisomeric substances, as indicated in Figure 5. 
Table 2. NMR Data $\left({ }^{1} \mathrm{H} 700 \mathrm{MHz}\right.$ and $\left.{ }^{13} \mathrm{C} 175 \mathrm{MHz}, \mathrm{CDCl}_{3}\right)$ of 2.

\begin{tabular}{|c|c|c|c|c|}
\hline Position & $\delta_{C}$ & Type $^{a}$ & $\delta_{H}(J$ In $\mathrm{Hz})$ & НМВС \\
\hline $1 \mathrm{a}$ & 20.2 & $\mathrm{CH}_{2}$ & 1.76, qd $(14.3,3.5)$ & 3 \\
\hline $1 b$ & & & $1.56, \mathrm{dt}(14.3,2.8)$ & 10 \\
\hline $2 a$ & 41.6 & $\mathrm{CH}_{2}$ & 1.88, brd (13.0) & $1,3,10,20 *$ \\
\hline $2 b$ & & & $1.19, \operatorname{td}(13.0,3.7)$ & $1,3,9,10,20$ * \\
\hline $3 a$ & 40.4 & $\mathrm{CH}_{2}$ & 2.38, brd (13.0) & $1,2,4$ \\
\hline $3 b$ & & & $1.01, \mathrm{td}(13.0,3.7)$ & $1,4,5,18,19$ \\
\hline 4 & 46.6 & $\mathrm{C}$ & & \\
\hline 5 & 57.5 & $\mathrm{CH}$ & 1.46, brs & $4,6,9,10,18,19,20$ \\
\hline 6 & 67.9 & $\mathrm{CH}$ & 4.52, brq $(2.6)$ & $4,5,7,8,10$ \\
\hline $7 a$ & 45.4 & $\mathrm{CH}_{2}$ & 2.50, dd $(13.6,2.6)$ & $5,6,8,9,17$ \\
\hline $7 \mathrm{~b}$ & & & 2.34, brd (13.6) & $6,8,9,17$ \\
\hline 8 & 133.9 & $\mathrm{C}$ & & \\
\hline 9 & 56.7 & $\mathrm{CH}$ & 1.82, brd (11.1) & $5,7,8,10,11,17,20$ \\
\hline 10 & 41.3 & $\mathrm{C}$ & & \\
\hline $11 \mathrm{a}$ & 23.4 & $\mathrm{CH}_{2}$ & $2.40, \mathrm{~m}$ & $8,9,12,13,15$ \\
\hline $11 b$ & & & $2.23, \operatorname{ddd}(16.6,11.3,6.4)$ & $9,12,13$ \\
\hline 12 & 132.9 & $\mathrm{CH}$ & 5.41, brt $(6.4)$ & $9,11,14,16$ \\
\hline 13 & 142.3 & $\mathrm{C}$ & & \\
\hline 14 & 141.4 & $\mathrm{CH}$ & $6.32, \mathrm{dd}(17.4,10.8)$ & 12,16 \\
\hline $15 a$ & 110.3 & $\mathrm{CH}_{2}$ & $5.06, \mathrm{~d}(17.4)$ & 12,14 \\
\hline $15 b$ & & & $4.90, \mathrm{~d}(10.8)$ & 12,14 \\
\hline 16 & 11.9 & $\mathrm{CH}_{3}$ & $1.76, \mathrm{~s}$ & 12,14 \\
\hline $17 a$ & 111.9 & $\mathrm{CH}_{2}$ & 5.03, brs & $7,8,9$ \\
\hline $17 \mathrm{~b}$ & & & $4.76, \mathrm{brs}$ & $7,8,9$ \\
\hline 18 & 28.4 & $\mathrm{CH}_{3}$ & $1.33, \mathrm{~s}$ & $3,4,5$ \\
\hline 19 & 180.2 & $\mathrm{C}$ & & \\
\hline 20 & 15.8 & $\mathrm{CH}_{3}$ & $0.87, \mathrm{~s}$ & 9,10 \\
\hline
\end{tabular}

a According to HSQC spectrum; ${ }^{*}$ Through four-bonds interaction.

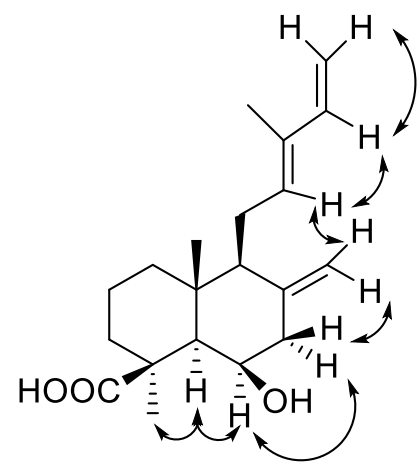

Figure 4. Key NOESY interactions observed for compound 2. 
<smiles>C=C/C(C)=C/C[C@H]1C(=C)C[C@@H](O)[C@]2(C)[C@@H]1CCC[C@]2(C)C(=O)O</smiles>

Deacetylzanzibaric acid

m. p. $=202-205{ }^{\circ} \mathrm{C}$

$[\alpha]_{D}=-17\left(c=0.4, \mathrm{CHCl}_{3}\right)$<smiles>C=C/C(C)=C/C[C@H]1C(=C)C[C@@H](O)[C@H]2[C@@](C)(C(=O)O)CCC[C@]12C</smiles>

6 $\beta$-hydroxy-trans-communic acid (2)

m. p. $=170-173^{\circ} \mathrm{C}$

$[\alpha]_{D}=+23.02\left(c=0.265, \mathrm{CHCl}_{3}\right)$

Figure 5. Comparison of some physical properties of deacetylzanzibaric acid with compound 2.

Compound 3, isolated from this population of S. cinnabarina, was identified as trans-communic acid based on its spectroscopic properties and comparison with literature data [29]. Even though trans-communic acid (3) has been obtained from various natural sources [30], it was first isolated from Juniperus communis L. (Cupressaceae) [31]. The structure and configuration of this compound were established by extensive chemical transformations of the natural acid, its sodium salt and derivatives, as well as by correlation with labdane-type diterpenes of known configuration such as torulosol and manool [16]. In 1987 Shie-Ming Peng et al. confirmed the structure and relative configuration by X-ray diffraction study of the methyl ester obtained from trans-communic acid (3), isolated from fresh leaves of Calocedrus formosana Florin [32]. In this study, meticulous attempts to crystallize trans-communic acid (3) were successful and crystals of the natural product which were suitable for X-ray diffraction were obtained. Figure 6 shows the computer-generated projection of the natural enantiomer of trans-communic acid (3). The absolute configuration was confirmed by calculating the Flack parameter whose value, $x=0.1$ (3), confirms the absolute configuration shown in structure 3 . Based on the above data the absolute configuration of trans-communic acid (3) was stablished as 4S5R9S10R.

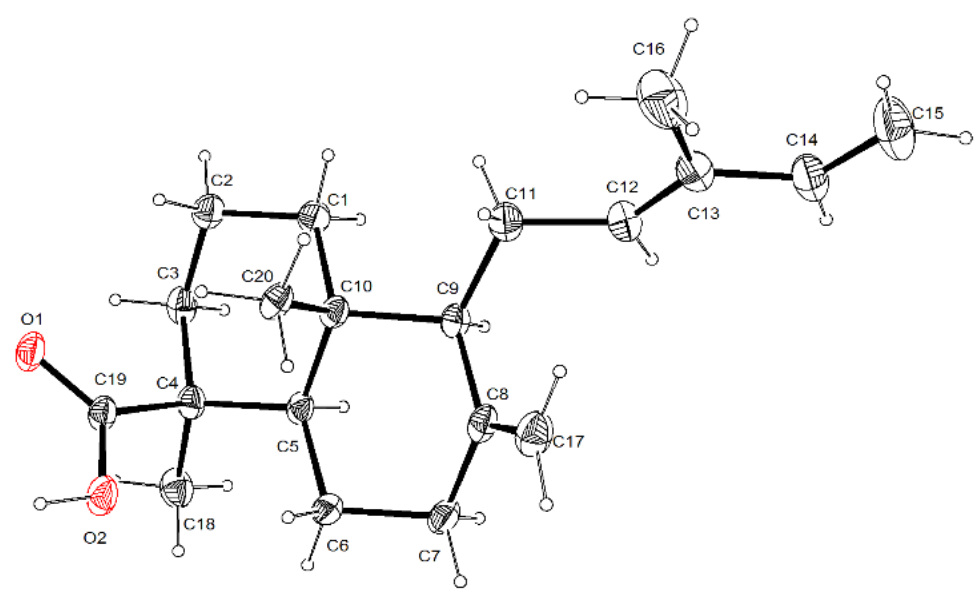

Figure 6. PLUTO plots of the single crystal X-ray diffraction structures of trans-communic acid (3).

It is important to point out that labdane diterpenes have been isolated from several other species of the genus Salvia, such as Salvia sclarea L., S. officinalis L., S. palaestina Benth., S. aethiopis L., S. yosgadensis Freyn and Bornm [33], S. leriaefolia Benth. [34], S. rhytidea Benth. [35] and S. reuterana Boiss [36] which grow in Europe or the Middle East. This is the first time that labdane type diterpenoids have been isolated from a sage of the subgenus Calospahce. It is also important to mention that previous studies of S. cinnabarina (cultivated material) do not describe this type of diterpenes. 
Another labdane diterpenoid isolated from this species was identified as trans-communol (4), which was first obtained by reduction with $\mathrm{LiAlH}_{4}$ of the trans-communic acid methyl ester [16]. Trans-communol (4) has also been isolated from various natural sources, such as Pinus thunbergii Lamb. [37], Chamaecyparis obtusa (Siebold and Zucc.) Endl. [29], C. formosensis Matsum. [38] and Fritillariae thunbergii Miq. [39] among others. Trans-communol (4) has also been identified in the pyrolysis products of amber [40].

Two pimarane-type diterpenoids were also isolated from the dichloromethanic extract of this population of S. cinnabarina and identified as isopimara-7,15-dien-3-one (5) and isopimara-7,15-dien-3-ol (6). Their structures were established by spectroscopic means and comparison with literature data of previously described compounds isolated from other natural sources, including vegetable for example, Guarea macrophylla Vahl [41] and Nepeta clarkei Hook.f. [42], and even in the feces of the flying squirrel Trogopterus xanthipes Milne-Edwards [43]. According to the biogenetic hypothesis shown in Scheme 1, both isopimarane diterpenoids (5 and 6) can be considered precursors of 3,4-seco-isopimara-4(18),7,15-trien-3-oic acid (12), which was previously isolated from the foliar exudate of cultured S. cinnabarina.<smiles>C=C[C@]1(C)CCC2C(=CC[C@@H]3[C@@H](C)[C@H](O)CC[C@@]23C)C1</smiles><smiles>C=C[C@]1(C)CCC2C(=CC[C@H]3[C@@H](C)C(=O)CC[C@@]23C)C1</smiles>

5<smiles>C=C[C@]1(C)CCC2C(=CC[C@@H]3C(C)(C)OC(=O)CC[C@]23C)C1</smiles><smiles>C=C[C@]1(C)CCC2C(=CC[C@H](C(=C)C)[C@@]2(C)CCC(=O)O)C1</smiles>

12

Scheme 1. Biogenetic hypothesis to compound 12 starting from isopimarane 6.

Two sesquiterpenes 7 and 8 were also isolated from $S$. cinnabarina and identified based on their spectroscopic data as $\beta$-eudesmol (7) and cryptomeridiol (8) respectively. $\beta$-eudesmol (7) has been isolated from various plant sources, for example, from Manglietia hookeri Cubbil and W.W.Sm. (Magnoliaceae [44], Ocimum basilicum L. (Lamiaceae) [45] and Salvia microphylla Kunth (Lamiaceae) [46]. Cryptomeridiol (8) has been previously described from Phaulopsis imbricata (Forssk.) Sweet, Artemisia pygmaea A. Gray and Blumea basalmifera (L.) DC. [47].

The aromatic products 9-11, also isolated from the dichloromethanic extract of Salvia cinnabarina were identified by spectroscopic means as the flavonoid salvigenin (11), phthalic acid (9) and a mixture of saturated fatty acids esters with tyrosol (4-hydroxyphenethyl alcohol) (10). Salvigenin (11) was originally isolated from Salvia triloba L.f [48] and has subsequently been described in several species of the genus, such as S. barrelieri Benth. [49], S. dominica L. [50], S. apiana Jeps. [51] and S. sahendica Boiss. and Bushe [52] among others. Several biological activities have been described for this flavonoid including anti-inflammatory, analgesic, anticancer and vasorelaxant [53].

Phthalic acid esters, derived from the esterification of phtalic acid (9) with long chain alcohols, have been isolated from various plant sources, for example, Ajuga bracteosa Wall. ex Benth. (Lamiaceae) [54], Hedyotis uncinella Hook. and Arn. (Rubiaceae) [55] and Phyllantus rheedii Wight. (Euphorbiaceae) [56] 
and also from marine organisms such as the red algae Acantophora spicifera (M. Vahl) Børgesen (Rhodomelaceae) [57]. Free phthalic acid is a product of the degradation of its esters by the action of some bacteria and it is known that it can have harmful effects by promoting the formation of reactive oxygen species causing cellular damage as described in Malus prunifolia (Willd.) Borkh [58]. Laboratory experiments determined that wheat, corn and soybean plants are capable of incorporating phthalic acid when the seeds are germinated in soil where this compound has been added [59]. Thus, the presence of 9 in S. cinnabarina raises the question of whether it is genetically part of the chemical composition, or whether this species incorporated phthalic acid from the soil where it grew.

The last aromatic compound was identified, based on its spectroscopic characteristics, as a mixture of esters of fatty acids with tyrosol. However, due to the low amount isolated, it was not possible to establish the size of the fatty acid chains. HPLC-MS analysis (Q-TOF) indicates the presence of a mixture of tyrosol fatty acids esters of more than 30 carbon atoms. These types of tyrosol derivatives have been previously isolated from different plant species $[60,61]$ including a population of Salvia microphylla cultivated in Turkey [46]. Fatty acids esters of tyrosol had not been previously described in the chemical and biological analyses of Mexican sage.

\subsection{Biological Activity}

\subsubsection{Anti-Inflammatory Activity}

Compounds 6 $\beta$-hydroxy-trans-communic acid (2), trans-communic acid (3) and $\beta$-eudesmol (7) were tested as anti-inflammatory in the edema model induced by TPA. The percentages of inhibition obtained at $1.0 \mu \mathrm{mol} /$ ear in a primary screening were $21.72 \%, 9.09 \%$ and $9.51 \%$, respectively, so none of them showed significant activity.

\subsubsection{Inhibition of $\alpha$-Glucosidase Activity}

Malonylcommunol (1), 6 $\beta$-hydroxy-trans-communic acid (2) and trans-communic acid (3) were evaluated as $\alpha$-glucosidase inhibitors in yeast and mammalian $\alpha$-glucosidases. In a primary screening, using yeast $\alpha$-glucosidase compounds 1-3 showed the highest inhibition of the enzyme, however the activity of the compounds decreased significantly in the mammalian $\alpha$-glucosidase, evidencing a high specificity towards yeast $\alpha$-glucosidase. Figure 7 shows that the effect of the evaluated compounds in yeast $\alpha$-glucosidase is dependent of the concentration. Malonylcommunol (1) was the most active compound $\left(\mathrm{IC}_{50} 20.96 \pm 0.58 \mu \mathrm{M}\right)$, close to the reference compound quercetin $\left(\mathrm{IC}_{50} 16.72 \pm 0.61 \mu \mathrm{M}\right)$. Compounds 2 and 3 showed lower effect with $\mathrm{IC}_{50}=43.74 \pm 4.14$ and $45.15 \pm 3.76$ respectively.

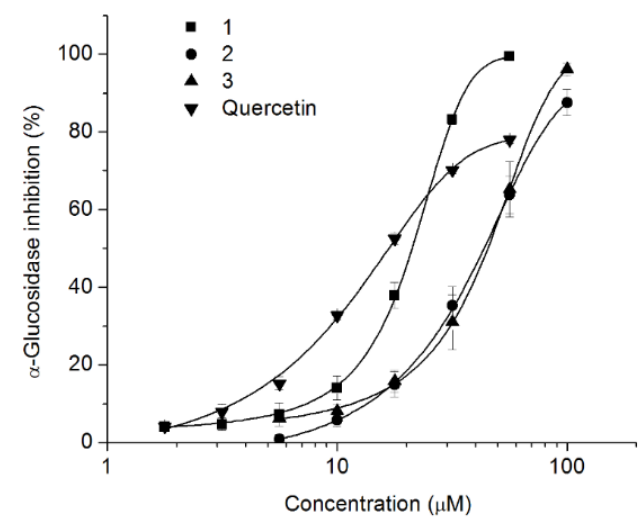

Figure 7. Concentration-response evaluation of compounds 1-3 isolated from S. cinnabarina on yeast $\alpha$-glucosidase inhibition. Each value represents the mean of three independent experiments \pm SEM; The data were analyzed by ANOVA followed by Dunnet post hoc test for comparison with control group. 


\section{Materials and Methods}

\subsection{Experimental}

The melting points (uncorrected) were determined on a Fisher-Johns (Fisher Scientific Company, Pittsburgh, PA, USA) apparatus. The optical rotations were measured on a Perkin-Elmer 323 polarimeter (Perkin Elmer Inc., London, UK). The ECD spectra were recorded on a Jasco J-1500 spectropolarimeter (Jasco, Tokyo, Japan) in $\mathrm{MeOH}$ at 1000 ppm. The IR spectra were obtained on a Bruker Tensor 27 spectrometer (Bruker, Ettlingen, Germany); 1D and 2D NMR experiments were performed on a Bruker Advance III HD spectrometer (Bruker BioSpin $\mathrm{GmbH}$, Rheinstetten, Germany) at $500 \mathrm{MHz}$ for ${ }^{1} \mathrm{H}$ and $125 \mathrm{MHz}$ for ${ }^{13} \mathrm{C}$ and on a Bruker Advance III HD spectrometer (Bruker BioSpin GmbH, Rheinstetten, Germany) at $700 \mathrm{MHz}$ for ${ }^{1} \mathrm{H}$ and $175 \mathrm{MHz}$ for ${ }^{13} \mathrm{C}$, using $\mathrm{CDCl}_{3}$ as solvent. Chemical shifts were referred to residual $\mathrm{CHCl}_{3}\left(\delta_{\mathrm{H}}=7.26, \delta_{\mathrm{C}}=77.16\right)$. The DART-MS data were obtained on a Jeol, The AccuTOF JMS-T100LC mass spectrometer. (Jeol Ltd., Tokyo, Japan) The X-ray data were collected on a Bruker D8 Venture (Bruker AXS GmbH, Karlsruhe, Germany) using CuK $\alpha(\lambda=1.54178 \AA)$. Silica gel 230-400 mesh (Macherey-Nagel, Nagel, Macherey Nagel, Düren, Germany), Sephadex LH-20 (Pharmacia Biotech AB, Uppsala, Sweden) and octadecyl-functionalized silica gel (Sigma-Aldrich, St. Louis, MO, USA) were used for column chromatography.

\subsection{Plant Material}

Salvia cinnabarina Martens and Galeotti was collected in Zoquitlan, State of Puebla, Mexico, in December 2017. Coordenates: $18^{\circ} 20^{\prime} 3.6^{\prime \prime} \mathrm{N}, 96^{\circ} 59^{\prime} 37.5^{\prime \prime} \mathrm{W}$. Plant material was identified by Dr. Martha Martínez-Gordillo, and a voucher specimen (FCME 161531) was deposited at the Herbarium (FCME) of the Facultad de Ciencias (Mexico City, Mexico), UNAM. A photograph of the voucher is included as supplementary material.

\subsection{Extraction and Isolation}

The dried and powdered aerial parts of S. cinnabarina (370 g) were extracted exhaustively by percolation with $\mathrm{CH}_{2} \mathrm{Cl}_{2}$ (DCM). The DCM extract was concentrated at reduced pressure to yield $16 \mathrm{~g}$ of residue. The crude extract ( $16 \mathrm{~g}$ ) was subjected to CC on silica gel using petrol: EtOAc (100: 0- 0: 100) as mobile phase to obtain 44 eluates, $250 \mathrm{~mL}$ each, which were combined in fifteen major fractions (A-O) after TLC evaluation. Fraction B (200 mg) was purified by CC on Sephadex LH-20, eluting with petrol: DCM: $\mathrm{MeOH}(3: 1: 1)$ as the mobile phase to obtain seventeen fractions (B1-B17), $10 \mathrm{~mL}$ each. Fraction B5 (25 mg) was purified by TLC using petrol: acetone (98: 2) as mobile phase to give the compound isopimara-7,15-dien-3-one (5, $10.5 \mathrm{mg})$. Trans-communic acid (3, 146.2 $\mathrm{mg})$ was isolated from fraction B7. A mixture of tyrosol derivatives $(\mathbf{1 0}, 7.2 \mathrm{mg})$ was identified in fraction C. Fraction D was subjected to CC on Sephadex LH-20 using MeOH as mobile phase to obtain fourteen fractions (D1-D14), $5 \mathrm{~mL}$ each. Fraction D10 was purified by TLC on ODS, using ACN: $\mathrm{H}_{2} \mathrm{O}$ (4: 1) to yield compounds isopimara-7,15-dien-3 $\beta$-ol (6, $4.2 \mathrm{mg})$ and $\beta$-eudesmol (7, $10.3 \mathrm{mg})$. Fraction E (145 mg) was subjected to CC on Sephadex LH-20 (Pharmacia Biotech AB, Uppsala, Sweden) eluting with petrol: DCM: MeOH: Formic acid (3:1:1:0.5\%) to obtain 54 fractions (E1-E54), 3 mL each. Fractions E24-E25 (25 mg) were combined and purified by CC using DCM: EtOH (98: 2) to obtain trans-communol (4, $4.7 \mathrm{mg})$. Phthalic Acid (9, $25 \mathrm{mg})$ was identified from fraction F. Fraction K (75 mg) was subjected to CC on Sephadex LH-20 using MeOH as mobile phase to obtain 15 fractions which were combined in five major fractions (KA-KE) after TLC evaluation. Fractions KB (70 mg) and KD (15 mg) were purified by TLC on ODS using $\mathrm{MeOH}: \mathrm{H}_{2} \mathrm{O}$ (3: 1) to give malonylcommunol (1, $5.3 \mathrm{mg}$ ), and petrol: acetone (95: 5) to give salvigenin (11, $6 \mathrm{mg})$, respectively. Fraction L (938 mg) was subjected to CC on Sephadex LH-20 using $\mathrm{MeOH}$ as mobile phase to obtain fifteen fractions (L1-L15), $20 \mathrm{~mL}$ each, which were combined in four mayor fractions (LA-LD) after TLC evaluation. Fraction LC (302 mg) was subjected to CC on Sephadex LH-20 using petrol: DCM: MeOH (1: 1: 3) to obtain 20 fractions, $5 \mathrm{~mL}$ each, which 
were combined in seven major fractions (LCA-LCG); Fraction LCD afforded cryptomeridiol (8, $9.3 \mathrm{mg}$ ), while $6 \beta$-hydroxy-trans-communic acid $(2,40.3 \mathrm{mg})$ was isolated from fraction LD.

Malonylcommunol (1): white powder; m.p. $85-90^{\circ} \mathrm{C} ;[\alpha]_{D}{ }^{589}=+2.2(c 0.10, \mathrm{MeOH}) ; \mathrm{IR}\left(\mathrm{CHCl}_{3}\right) v_{\max }$ $3607,3512,2933,2854,1732,1624 \mathrm{~cm}^{-1} ;{ }^{1} \mathrm{H}$ and ${ }^{13} \mathrm{C}$ NMR, see Table 1 ; HRDARTMS $\mathrm{m} / z[\mathrm{M}+\mathrm{H}]^{+}$ 375.25347 (calculated for $\mathrm{C}_{23} \mathrm{H}_{35} \mathrm{O}_{4}, 375.25353$ ).

6 $\beta$-Hydroxy-trans-communic acid (2): white powder; m.p. $170-173{ }^{\circ} \mathrm{C} ;[\alpha]_{\mathrm{D}}{ }^{589}=+23.0($ c $0.50, \mathrm{MeOH})$; IR $\left(\mathrm{CHCl}_{3}\right) v_{\max } 3601,3591,2941,2853,1726,1519,1406,1239,1223 \mathrm{~cm}^{-1} ;{ }^{1} \mathrm{H}$ and ${ }^{13} \mathrm{C}$ NMR, see Table 2; HRDARTMS $m / z[\mathrm{M}+\mathrm{H}]^{+} 319.24747$ (calculated for $\mathrm{C}_{20} \mathrm{H}_{31} \mathrm{O}_{3}, 319.24845$ ).

Trans-communic acid (3): colorless crystals; m.p. $118-120$ (reported $\left.135-137^{\circ} \mathrm{C}\right) ;[\alpha]_{\mathrm{D}}{ }^{589}=+45.3(\mathrm{c} 0.40$, $\left.\mathrm{CHCl}_{3}\right)$ (reported $\left.+47.7 ; \mathrm{c} 0.45, \mathrm{CHCl}_{3}\right)$; NMR data were essentially the same as reported [29].

Trans communol (4): colorless oil; $[\alpha]_{\mathrm{D}}{ }^{589}=+4.6\left(\right.$ c $\left.0.61, \mathrm{CHCl}_{3}\right)\left(\left(\right.\right.$ reported $\left.+18.0, \mathrm{CHCl}_{3}\right) ; \mathrm{IR}\left(\mathrm{CHCl}_{3}\right)$ $v_{\max } 3629,2872,2852,1723,1642,1451,1384,1209,1018,908,895 \mathrm{~cm}^{-1} .{ }^{1} \mathrm{H} \mathrm{NMR}\left(\mathrm{CDCl}_{3}, 500 \mathrm{MHz}\right) \delta$ $6.33(1 \mathrm{H}, \mathrm{dd}, J=17.4,10.7 \mathrm{~Hz}, \mathrm{H}-14), 5.40(1 \mathrm{H}, \mathrm{t}, J=6.5 \mathrm{~Hz}, \mathrm{H}-12), 5.04(1 \mathrm{H}, \mathrm{d}, J=17.4 \mathrm{~Hz}, \mathrm{H}-15 \mathrm{a}), 4.88$ $(1 \mathrm{H}, \mathrm{d}, J=10.7 \mathrm{~Hz}, \mathrm{H}-15 \mathrm{~b}), 4.81(1 \mathrm{H}, \mathrm{brq}, J=1.5 \mathrm{~Hz}, \mathrm{H} 17 \mathrm{a}), 4.46(1 \mathrm{H}, \mathrm{brq}, J=1.5 \mathrm{~Hz}, \mathrm{H} 17 \mathrm{~b}), 3.77(1 \mathrm{H}$, d, $J=10.8 \mathrm{~Hz}, \mathrm{H} 19 \mathrm{a}), 3.41(1 \mathrm{H}, \mathrm{d}, J=10.8 \mathrm{~Hz}, \mathrm{H} 19 \mathrm{~b}), 2.42-2.37(2 \mathrm{H}, \mathrm{m}, \mathrm{H}-7 \mathrm{a}, \mathrm{H}-11 \mathrm{a}), 2.13$ (1H, ddd, $J=16.5,11.0,6.8 \mathrm{~Hz}, \mathrm{H}-11 \mathrm{~b}), 1.96(1 \mathrm{H}, \mathrm{td}, J=12.8,6.7 \mathrm{~Hz}, \mathrm{H}-7 \mathrm{~b}), 1.77-1.86$ (4H, m, H-1a, H-3a, H-6a, $\mathrm{H}-9), 1.75\left(3 \mathrm{H}, \mathrm{brs}, \mathrm{CH}_{3}-16\right), 1.52\left(2 \mathrm{H}, \mathrm{m}, \mathrm{CH}_{2}-2\right), 1.32(1 \mathrm{H}, \mathrm{td}, J=12.6,4.1 \mathrm{~Hz}, \mathrm{H}-6 \mathrm{~b}), 1.28(1 \mathrm{H}, \mathrm{m}, \mathrm{H}-5)$, $1.13(1 \mathrm{H}, \mathrm{td}, J=12.3,5.4 \mathrm{~Hz}, \mathrm{H} 1 \mathrm{~b}), 1.01-1.95(1 \mathrm{H}, \mathrm{m}, \mathrm{H}-3 \mathrm{~b}), 0.99\left(3 \mathrm{H}, \mathrm{s}, \mathrm{CH}_{3}-18\right), 0.70\left(3 \mathrm{H}, \mathrm{s}, \mathrm{CH}_{3}-20\right)$; ${ }^{13} \mathrm{C}$ NMR $\left(\mathrm{CDCl}_{3}, 126 \mathrm{MHz}\right) \delta 148.2$ (C-8), 141.8 (C-14), 134.1 (C-12), 133.6 (C-13), 110.0 (C-17), 107.9 (C-15), 65.3 (C-19), 57.3 (C-9), 56.4 (C-5), 39.6(C-10), 39.3 (C-1), 39.0 (C-4), 38.5 (C-7), 35.5 (C-3), 27.2 (C-18), 24.4 C-6), 23.4 (C-11), 19.2 (C-2), 15.4 (C-20), 12.0 (C-16). DARTMS m/z 289.

Isopimara-7,15-dien-3-one (5): white powder; m.p. 80-82 ${ }^{\circ} \mathrm{C}$ (reported $\left.91-92{ }^{\circ} \mathrm{C}\right) ;[\alpha]_{\mathrm{D}}{ }^{589}=-70(\mathrm{c} 0.26$, $\left.\mathrm{CHCl}_{3}\right)$ ((reported-82, $\left.\mathrm{CHCl}_{3}, \mathrm{c} 2.0\right)$ [62]; IR $\left(\mathrm{CHCl}_{3}\right) v_{\max } 2919,2869,1702,1638,1455,1386,1206,1000$, $915,845 \mathrm{~cm}^{-1} .{ }^{1} \mathrm{H}$ NMR $\left(\mathrm{CDCl}_{3}, 700 \mathrm{MHz}\right) \delta 5.81(1 \mathrm{H}, \mathrm{dd}, J=17.5,10.7 \mathrm{~Hz}, \mathrm{H}-15), 5.41(1 \mathrm{H}, \mathrm{brs}, \mathrm{H}-7)$, $4.94(1 \mathrm{H}, \mathrm{dd}, J=17.5,1.3 \mathrm{~Hz}, \mathrm{H}-16 \mathrm{a}), 4.88(1 \mathrm{H}, \mathrm{dd}, J=10.7,1.3, \mathrm{H}-16 \mathrm{~b}), 2.70(1 \mathrm{H}, \mathrm{td}, J=14.6,5.3 \mathrm{~Hz}$, H-2a), $2.70(1 \mathrm{H}, \mathrm{td}, J=14.6,3.8 \mathrm{~Hz}, \mathrm{H}-2 \mathrm{~b}), 2.13-2.08(2 \mathrm{H}, \mathrm{m}, \mathrm{H}-1, \mathrm{H}-6), 1.98(1 \mathrm{H}, \mathrm{brd}, J=13.9 \mathrm{~Hz}$, H-14a), $1.94(1 \mathrm{H}, \mathrm{td}, J=13.9,2.5 \mathrm{~Hz}, \mathrm{H} 14 \mathrm{~b}), 1.90(1 \mathrm{H}, \mathrm{m}, \mathrm{H}-6 \mathrm{~b}), 1.71(1 \mathrm{H}, \mathrm{m}, \mathrm{H}-9), 1.60(2 \mathrm{H}, \mathrm{m}, \mathrm{H}-11)$, 1.55 (1H, dd, $J=11.9,4.1 \mathrm{~Hz}, \mathrm{H}-5), 1.52-1.49$ (2H, m, H1b, H12a), 1.35-1.45 (2H, m, H-11b, H-12b), 1.13

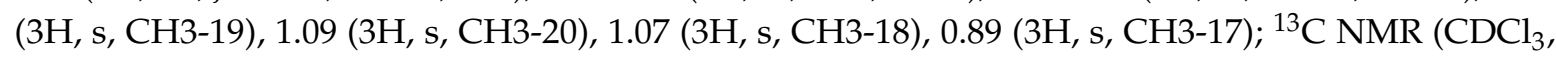
$175 \mathrm{MHz}) \delta 217.1$ (C-3), 150.2 (C-15), 135.8 (C-8), 121.3 (C-7), 109.6 (C-16), 51.9 (C-5), 51.2 (C-9), 47.6 (C-4), 46.1 (C-14), 38.3 (C-1), 37.0 (C-13), 36.2 (C-152), 35.4 (C-10), 34.9 (C-2), 25.7 (C-18), 24.0 (C-6), 22.8 (C-19), 21.7 (C-17), 20.4 (C-11), 15.0 (C-20).

Isopimara-7,15-dien-3-ol (6): colorless oil; $[\alpha]_{\mathrm{D}}{ }^{589}=-8.0\left(\right.$ c $0.18, \mathrm{CHCl}_{3}$; $\mathrm{NMR}$ data were essentially the same as reported.

\subsection{Computational Details}

3D models for compounds 3 and 4 were built, and geometry optimized using Spartan' 10 utilizing a Merck Molecular Force Field (MMFF). Conformational analysis was performed with the same software under a PM3 semiempirical force field. The resulting conformers were filtered and checked for redundancy. All conformers within $4 \mathrm{kcal} / \mathrm{mol}$ were minimized, optimized and the thermochemical properties, IR and vibrational frequencies calculated using the DFT-B3LYP/DGDZVP force field in Gaussian 09. The TD-SCF with the default solvent model was used to perform the ECD calculations of the major conformers in MeOH solution at the B3LYP/6-31G* (d) level of theory. The calculated excitation energy $(\mathrm{nm})$ and rotatory strength $(R)$ in dipole velocity $\left(R_{v e l}\right)$ form were simulated into 
an ECD curve using the Harada-Nakanishi equation (Equation (1)) as implemented in the SpecDis software [63-65]. All calculations were performed on the HP Cluster Platform 3000SL “Miztli."

$$
\Delta \varepsilon(v)=\sum_{i=1}^{n} \Delta \varepsilon_{i}(v)=\sum_{i=1}^{n}=\frac{R_{i}}{2.296 \times 10^{-39} \sqrt{\pi}} \frac{v_{i}}{\sigma} e\left[-\left(\frac{v-v_{i}}{\sigma}\right)^{2}\right]
$$

\subsection{Single-Crystal X-ray Diffraction Analysis for Trans-Communic Acid (3)}

A colorless crystal was selected for experimental diffraction and mounted in a D8 venture $\mathrm{K}$ geometry diffractometer (Bruker AXS GmbH, Karlsruhe, Germany) with micro-focus X-ray source $\mathrm{Cu} \mathrm{k} \alpha$ radiation $(\lambda=1.54178 \AA$ ). The detector was placed at $50 \mathrm{~mm}$ from the crystal. Frames were collected with a scan width of $0.3^{\circ}$ in the $\omega$ scan and the exposure time of $10 \mathrm{sec} /$ frame at $298 \mathrm{~K}$. Frames were integrated with the Bruker SAINT software package (Bruker AXS Inc., Madison, Wisconsin, USA) using a narrow-frame integration algorithm. Systematic absences and intensity statistics were used in system orthorhombic, space group $\mathrm{P} 2{ }_{1} 2_{1} 2_{1}$. The structure was solved using direct methods using SHELXS-2014/7 program [66]. Hydrogen atoms were input at calculated positions and allowed to ride on the atoms to which they are attached. Thermal parameters were refined for hydrogen atoms on the aromatic ring and methylene using a $U e q=1.2 \AA$ and a $U e q=1.5 \AA$ for methyl groups to precedent atom in all cases. The final cycle of refinement was carried out on all non-zero data using SHELXL-2014/7 [66]. The Flack parameter was determined as 0.1(1) and confirmed with Bayesian parameters [67] P2 (true) $=1.000$, P3 (false) $=0.3 \mathrm{E}-2$ and Pearson $\mathrm{z}=0.38(11)$.

The trans-communic acid (3) was determined with two molecules crystallographically independent with an labdane-type structure, in according with Cremer and Pople puckering parameters [68] A-B rings has a chair conformation $\left(\mathrm{A} 1 \operatorname{ring} \mathrm{Q}=0.540(3)\right.$, Theta $=0.0(3)^{\circ}, \mathrm{Phi}=100(19)^{\circ}, \mathrm{B} 1 \operatorname{ring} \mathrm{Q}=0.576(3)$, Theta $=0.6(3) \mathrm{Deg}, \mathrm{Phi}=289(6)^{\circ}, \mathrm{A} 2$ ring $(\mathrm{Q})=0.542(3)$, Theta $=3.4(3)^{\circ}, \mathrm{Phi}=125(6)^{\circ}$ and $\mathrm{B} 2$ ring $(\mathrm{Q})=$ $0.593(3)$, Theta $\left.=2.0(3)^{\circ}, \mathrm{Phi}=263(6)^{\circ}\right)$. The carboxylic acid is in an axial orientation in both molecules, and is forming a H-bonding with other carboxylic acid by symmetry code $1-x, 1 / 2+y, 1 / 2-z$.

Crystallographic data (excluding structure factors) were deposited at the Cambridge Crystallographic Data Centre (CCDC) under the reference numbers CCDC 1983658, and copies of the data can be obtained free of charge upon application to the CCDC, 12 Union Road, Cambridge CB2 IEZ, UK. Fax: +44-(0)1223-336033 or e-mail: deposit@ccdc.cam.ac.uk.

\subsection{TPA-Induced Edema Model}

Animals. Male CD-1 mice weighing 25-30 g were maintained under standard laboratory conditions in the animal house (temperature $24 \pm 2{ }^{\circ} \mathrm{C}$ ) in a 12/12 h light-dark cycle, being fed laboratory diet and water ad libitum, following the Mexican official norm NOM-062-Z00-1999. The experimental procedures were approved by Internal Ethic Committee (CICUAL-IQ-004-17).

The TPA-induced ear edema assay in mice was performed as reported [69]. A solution of TPA $(2.5 \mu \mathrm{g})$ in ethanol $(10 \mu \mathrm{L})$ was applied topically to both faces ( $5 \mu \mathrm{L}$ each ear) of the right ear of the mice, after $10 \mathrm{~min}$ the solutions of the test substances in their respective solvents were applied $(10 \mu \mathrm{L}$ each face). The left ear received ethanol $(10 \mu \mathrm{L})$ then $20 \mu \mathrm{L}$ of the respective solvent. The mice were killed with $\mathrm{CO}_{2}$ four hours later. A $7 \mathrm{~mm}$ diameter plug was removed from each ear. The swelling was assessed as the difference in weight between the left and the right ear. Control animals received the correspondent solvent in each case. Edema inhibition (EI\%) was calculated by the equation $\mathrm{EI} \%=100$ - $(\mathrm{B} \times 100 / \mathrm{A})$, where $\mathrm{A}$ is the edema induced by TPA alone and $\mathrm{B}$ is the edema induced by TPA plus sample. Indomethacin and celecoxib were used as reference compounds. 


\subsection{Inhibition of $\alpha$-Glucosidase}

\subsubsection{Inhibition of Yeast $\alpha$-Glucosidase}

$\alpha$-Glucosidase inhibition was evaluated using an adapted method of Xiao-Ping et al. 2010 and Zhou et al. 2010 [70,71]. A solution of tested samples $(25 \mu \mathrm{L})$ in DMSO- $\mathrm{H}_{2} \mathrm{O}$ 1:1 was added to $150 \mu \mathrm{L}$ of phosphate buffer solution (PBS, $67 \mathrm{mM}, \mathrm{pH}$ 6.8) and incubated at $37^{\circ} \mathrm{C}$ for 10 min with $25 \mu \mathrm{L}$ of reduced glutation ( $3 \mathrm{mM}$ in PBS) and $25 \mu \mathrm{L}$ of $0.2 \mathrm{U} \mathrm{mL}^{-1}$ in PBS solution of $\alpha$-glucosidase type I (Sigma cat. G5003-100UN). The substrate solution ( $25 \mu \mathrm{L}, 23.2 \mathrm{mM}$-nitrophenyl- $\alpha$-D-glucopyranoside, Sigma N1377-1G, in PBS) was added and incubated at $37{ }^{\circ} \mathrm{C}$ for an additional 15 min and shaken. Reaction mixture was stopped with $\mathrm{CaCO}_{3} 1 \mathrm{M}(50 \mu \mathrm{L})$ and after 5 min agitation the optical density was determined at $405 \mathrm{~nm}$. Quercetin was used as positive control. The inhibition percentage was calculated by the equation: Inhibition $(\%)=[($ Acontrol - Asample $) /$ Acontrol $] \times 100$. Where A is the absorbance at $405 \mathrm{~nm}$ of sample and control.

\subsubsection{Mammalian $\alpha$-Glucosidadse Inhibition Assay}

Mammalian $\alpha$-glucosidase was prepared following the modified method of Jo [72]. Rat-intestinal acetone powder $(100 \mathrm{mg})$ was rehydrated with $4 \mathrm{~mL}$ of $67 \mathrm{mM}$ ice cold phosphate buffer (pH 6.8). After homogenized in an OMNI International Tissue Homogenizer (Omni International, Inc., Kennesaw, GA, USA) (125 model) for $3 \mathrm{~min}$ at $4{ }^{\circ} \mathrm{C}$, the suspension was centrifuged $\left(13,400 \mathrm{rcf}, 4{ }^{\circ} \mathrm{C}, 30 \mathrm{~min}\right)$ and the resulting supernatant was used for the assay. A reaction mixture containing $175 \mu \mathrm{L}$ phosphate buffer (67 mM, pH 6.8), $25 \mu \mathrm{L}$ of $\alpha$-glucosidase supernatant and $25 \mu \mathrm{L}$ of sample at different concentrations (dissolved in DMSO 50\%), was pre-incubated for $10 \mathrm{~min}$ at $37^{\circ} \mathrm{C}$. Then $25 \mu \mathrm{L}$ of $23.2 \mathrm{mM} \mathrm{PNP-G}$ was added as a substrate. After further incubation of $15 \mathrm{~min}$ at $37^{\circ} \mathrm{C}$, the reaction was stopped whit $50 \mu \mathrm{L}$ of $\mathrm{Na}_{2} \mathrm{CO}_{3}(1 \mathrm{M})$. Acarbose and miglitol were used as a positive control and DMSO 5\% as negative control. Enzyme activity was quantified by measuring the absorbance at $405 \mathrm{~nm}$ in a BioTek microplate reader Synergy HT (BioTek Instruments, Winooski, VT. USA). Experiments were done in triplicates. The percentage of enzyme inhibition by the sample was calculated by the following formula: \% Inhibition $=[(\mathrm{AC}-\mathrm{AS}) / \mathrm{AC})] \times 100$, where $\mathrm{AC}$ is the absorbance of the negative control and AS is the absorbance of the tested sample. The concentration of an inhibitor required to inhibit $50 \%$ of enzyme activity under the mentioned assay conditions is defined as the inhibition concentration $50\left(\mathrm{IC}_{50}\right)$

\section{Conclusions}

From the dichloromethane extract of a wild population of Salvia cinnabarina, several natural products were isolated, including two unpublished labdane-type diterpenoids named malonylcommunol (1) and 6 $\beta$-hydroxy-trans-communic acid (2). Two already known labdane diterpenoids, trans-communic acid (3) and trans-communol (4) were also isolated and identified by spectroscopic means and comparison with literature date. Two isopimarane-type diterpenoids 5 and 6 were isolated together with two eudesmane-type sesquiterpenoids identified as $\beta$-eudesmol (7) and cryptomeridiol (8). Three aromatic natural products identified as phtalic acid (9), tyrosol derivatives (10) and the flavone salvigenin (11) were also isolated from this plant. Compounds 5 and 6 could be considered as biogenetic precursor of compound 12, a bioactive seco-isopimarane diterpenoid previously isolated from a cultivated population of S. cinnabarina. This work represented the first phytochemical analysis of a wild population of this plant.

Some products were tested in the TPA induced edema, anti-inflammatory assay with no significant results. The assay of compounds $\mathbf{1}-\mathbf{3}$ as $\alpha$-glucosidase inhibitors indicated high specificity towards yeast $\alpha$-glucosidase. Malonylcommunol (1) was the most active compound ( $\left.\mathrm{IC}_{50} 20.96 \pm 0.58 \mu \mathrm{M}\right)$, near to the reference compound quercetin. 
Supplementary Materials: The following are available online, Figure S1: ${ }^{1} \mathrm{H}$ NMR $\left(\mathrm{CDCl}_{3}, 700 \mathrm{MHz}\right)$ spectrum of 1, Figure S2. ${ }^{1} \mathrm{H}$ NMR $\left(\mathrm{CDCl}_{3}+\mathrm{D}_{2} \mathrm{O}, 700 \mathrm{MHz}\right)$ spectrum of 1, Figure $\mathrm{S} 3:{ }^{13} \mathrm{C} \mathrm{NMR}\left(\mathrm{CDCl}_{3}, 175 \mathrm{MHz}\right)$ spectrum of 1, Figure S4: COSY NMR $\left(\mathrm{CDCl}_{3}, 700 \mathrm{MHz}\right)$ spectrum of 1, Figure S5: HMBC NMR $\left(\mathrm{CDCl}_{3}, 700 \mathrm{MHz}\right)$ spectrum of 1, Figure S6: HSQC NMR ( $\left.\mathrm{CDCl}_{3}, 700 \mathrm{MHz}\right)$ spectrum of 1, Figure S7: NOESY NMR $\left(\mathrm{CDCl}_{3}, 700 \mathrm{MHz}\right)$ spectrum of 1, Figure S8: ${ }^{1} \mathrm{H}$ NMR $\left(\mathrm{CDCl}_{3}, 700 \mathrm{MHz}\right)$ spectrum of 2, Figure S9: ${ }^{13} \mathrm{C} \mathrm{NMR}\left(\mathrm{CDCl}_{3}, 175 \mathrm{MHz}\right)$ spectrum of 2 , Figure S10: COSY NMR $\left(\mathrm{CDCl}_{3}, 700 \mathrm{MHz}\right)$ spectrum of 2, Figure S11: $\mathrm{HMBC} \mathrm{NMR}\left(\mathrm{CDCl}_{3}, 700 \mathrm{MHz}\right)$ spectrum of 2, Figure S12: HSQC NMR $\left(\mathrm{CDCl}_{3}, 700 \mathrm{MHz}\right)$ spectrum of 2, Figure S13: NOESY NMR $\left(\mathrm{CDCl}_{3}, 700 \mathrm{MHz}\right)$ spectrum of 2. Figure S14. ${ }^{1} \mathrm{H} \mathrm{NMR}\left(\mathrm{CDCl}_{3}, 700 \mathrm{MHz}\right)$ spectrum of 4, Figure $\mathrm{S} 15 .{ }^{13} \mathrm{C} \mathrm{NMR}\left(\mathrm{CDCl}_{3}, 175 \mathrm{MHz}\right)$ spectrum of 4, Figure S16. ${ }^{1} \mathrm{H}$ NMR $\left(\mathrm{CDCl}_{3}, 700 \mathrm{MHz}\right)$ spectrum of 5, Figure $\mathrm{S} 17 .{ }^{13} \mathrm{C} \mathrm{NMR}\left(\mathrm{CDCl}_{3}, 175 \mathrm{MHz}\right)$ spectrum of 5, Figure S18. Herbarium specimen of Salvia cinnabarina and Table S1. Primary screening of the Inhibitory effect of compounds 2, 3 and 7 on TPA-induced inflammation in a mouse model, Table S2. Primary screening of inhibition of mammalian $\alpha$-glucosidase activity for compounds $\mathbf{1}$ and 2.

Author Contributions: B.E., C.B.-B. and L.Q. participated in the isolation and structure elucidation, preparation and revision of the manuscript. S.H.-O. participated in the collection, and analyses of $X$ ray data. A.N.-C. participated in the performance of TPA-induced edema model and $\alpha$-glucosidase inhibition test. Absolute configuration was determined by J.R.-C. All co-authors participated equally and substantially to the paper. All authors have read and agreed to the published version of the manuscript.

Funding: This research received no external funding.

Acknowledgments: In The authors acknowledge H. Rios, B. Quiroz, E. Huerta, A. Peña, R. Patiño, L. Velasco, C. García, J. Pérez and Everardo Tapia Mendoza for collecting NMR, UV, IR, MS data and HPLC analysis. The authors are indebted to Martha Martínez-Gordillo (Herbarium of the Faculty of Sciences of UNAM) for plant identification. This study made use of UNAM's NMR lab: LURMN at IQ-UNAM, which is funded by CONACYT Mexico (Project: 0224747). J Rivera-Chávez would like to thank Dirección General de Cómputo y de Tecnologías de Información y Comunicación (DGTIC), UNAM, for providing the resources to carry out computational calculations through the Miztli System. The authors thank to Jacklyn Gallagher for English language revision.

Conflicts of Interest: The authors declare no conflict of interest.

\section{References}

1. Gonzalez-Gallegos, J.G.; Aguilar-Santelises, R. Salvia tilantongensis (Lamiaceae), una especie nueva de la Mixteca alta de Oaxaca, México. Acta Bot. 2014, 109, 1-22. [CrossRef]

2. Jenks, A.A.; Kim, S.C. Medicinal plant complexes of Salvia subgenus Calosphace: An ethnobotanical study of new world sages. J. Ethnopharmacol. 2013, 146, 214-224. [CrossRef] [PubMed]

3. Cornejo-Tenorio, G.; Ibarra-Manríquez, G. Diversidad y distribución del género Salvia (Lamiaceae) en Michoacán, México Diversity and distribution of the genus Salvia (Lamiaceae) in Michoacan, Mexico. Rev. Mex. Biodivers. 2011, 82, 1279-1296.

4. De La Cruz-Jiménez, L.; Guzmán-Lucio, M.; Viveros-Valdez, E. Traditional medicinal plants used for the treatment of gastrointestinal diseases in Chiapas, México. World Appl. Sci. J. 2014, 31, 508-515.

5. Ascrizzi, R.; Cioni, P.L.; Amadei, L.; Maccioni, S.; Flamini, G. Geographical patterns of in vivo spontaneously emitted volatile organic compounds in Salvia species. Microchem. J. 2017, 133, 13-21. [CrossRef]

6. Bisio, A.; Ciarallo, G.; Romussi, G.; Fontana, N.; Mascolo, N.; Capasso, R.; Biscardi, D. Chemical composition of essential oils from some Salvia species. Phyther. Res. 1998, 12, 117-120. [CrossRef]

7. Romussi, G.; Ciarallo, G.; Bisio, A.; Fontana, N.; De Simone, F.; De Tommasi, N.; Mascolo, N.; Pinto, L. A new diterpenoid with antispasmodic activity from Salvia cinnabarina. Planta Med. 2001, 67, 153-155. [CrossRef]

8. Bisio, A.; Pagano, B.; Romussi, A.; Bruno, O.; De Tommasi, N.; Romussi, G.; Mattia, C.A. Relative stereochemistry of a diterpene from Salvia cinnabarina. Molecules 2007, 12, 2279-2287. [CrossRef]

9. Capasso, R.; Izzo, A.A.; Romussi, G.; Capasso, F.; De Tommasi, N.; Bisio, A.; Mascolo, N.A. Secoisopimarane diterpenoid from Salvia cinnabarina inhibits rat urinary bladder contractility in vitro. Planta Med. 2004, 70, 185-188.

10. Capasso, R.; Izzo, A.A.; Capasso, F.; Romussi, G.; Bisio, A.; Mascolo, N.A. Diterpenoid from Salvia cinnabarina inhibits mouse intestinal motility in vivo. Planta Med. 2004, 70, 375-377.

11. Alieri, A.; Maione, F.; Bisio, A.; Romussi, G.; Mascolo, N.; Cicala, C. Effect of a diterpenoid from Salvia cinnabarina on arterial blood pressure in rats. Phyther. Res. 2007, 21, 690-692. [CrossRef] [PubMed]

12. Maione, F.; Bonito, M.C.; Colucci, M.; Cozzolino, V.; Bisio, A.; Romussi, G.; Cicala, C.; Pieretti, S.; Mascolo, N. First evidence for an anxiolytic effect of a diterpenoid from Salvia cinnabarina. Nat. Prod. Commun. 2009, 4, 469-472. [CrossRef] [PubMed] 
13. Di Sotto, A.; Mastrangelo, S.; Romussi, G.; Bisio, A.; Mazzanti, G. Antimutagenic activity of a secoisopimarane diterpenoid from Salvia cinnabarina M. Martens et Galeotti in the bacterial reverse mutation assay. Food Chem. Toxicol. 2009, 47, 2092-2096. [CrossRef]

14. Di Sotto, A.; Carbone, F.; Hrelia, P.; Maffei, F.; Castelli, F.; Sarpietro, M.G.; Mazzanti, G. Anticlastogenic effect in human lymphocytes by the sodium Salt of 3,4-secoisopimar-4(18),7,15-trien-3-oic acid. J. Nat. Prod. 2012, 75, 1294-1298. [CrossRef] [PubMed]

15. Bustos-Brito, C.; Joseph-Nathan, P.; Burgueño-Tapia, E.; Martínez-Otero, D.; Nieto-Camacho, A.; Calzada, F.; Yépez-Mulia, L.; Esquivel, B.; Quijano, L. Structure and Absolute Configuration of Abietane Diterpenoids from Salvia clinopodioides: Antioxidant, Antiprotozoal, and Antipropulsive Activities. J. Nat. Prod. 2019, 82, 1207-1216. [CrossRef] [PubMed]

16. Arya, V.P.; Erdtman, H.; Kubota, T. Chemistry of the natural order Cupressales-41. The structure and stereochemistry of communic acid. Tetrahedron 1961, 16, 255-263. [CrossRef]

17. Garbarino, J.A.; Molinari, A. A labdane diterpene from Calcolaria corymbosa. J. Nat. Prod. 1993, 56, $624-626$. [CrossRef]

18. Garbarino, J.A.; Molinari, A. Labdane diterpenes from Calceolaria densifolia. J. Nat. Prod. 1992, 55, $744-747$. [CrossRef]

19. Hansen, E.W.; Ruoff, P. Estimation of malonic acid and methylmalonic acid enolization rate constants by an isotopic-exchange reaction using 1H NMR spectroscopy. J. Phys. Chem. 1988, 92, 2641-2645. [CrossRef]

20. Bohlmann, F.; Zdero, C.; Robinson, H.; King, R.M. Ein neues germacren-derivat sowie ein diterpenmalonat aus Baccharis-arten. Phytochemistry 1979, 18, 1993-1996. [CrossRef]

21. Toyota, M.; Asakawa, Y. Diterpenoid constituents of the liverwort Nardia subclavata. Phytochemistry 1993, 34, 751-753. [CrossRef]

22. Langenbahn, U.; Burkhardt, G.; Becker, H. Diterpene malonates and other terpenes from Nardia succulenta and N. scalaris. Phytochemistry 1993, 33, 1173-1179. [CrossRef]

23. Urones, J.G.; Marcos, I.S.; Cubillo, I.; Garrido, N.M.; Basabe, P. Terpenoid compounds from Parentucellia latifolia. Phytochemistry 1990, 29, 2223-2228. [CrossRef]

24. Urones, J.G.; Marcos, S.; Ferreras, J.F.; Barcala, P.B. Terpenoids from Nepeta tuberosa subsp. reticulata. Phytochemistry 1988, 27, 523-526. [CrossRef]

25. King, R.M.; Zdero, C.; Bohlmann, F.; Paz, L.; Botanical, M.; Index-baccharis, W. Ent-clerodanes and other constituents from bolivian Baccharis species. Phytochemistry 1989, 28, 531-542.

26. Bohlmann, F.; Wegner, P. Ent-beyer-15-ene derivatives from Nidorella anomala. Phytochemistry 1982, 21, 1175-1177. [CrossRef]

27. Labbe, C.; Castillo, M.; Hernandez, M. Diterpenoids from Baccharis lejia. Phytochemistry 1991, 30, $1607-1611$. [CrossRef]

28. Hugel, G.O.G. Diterpenes de Trachylobium. IV.-Structure et stereochemie de l'acide zanzibarique. Bull. Soc. Chim. Fr. 1965, 10, 2903-2908.

29. Fukushima, J.I.; Yatagai, M.; Ohira, T. Abietane-type and labdane-type diterpenoids from the cones of Chamaecyparis obtusa. J. Wood Sci. 2002, 48, 326-330. [CrossRef]

30. Barrero, A.F.; Herrador, M.M.; Arteaga, P.; Arteaga, J.F.; Arteaga, A.F. Communic acids: Occurrence, properties and use as chirons for the synthesis of bioactive compounds. Molecules 2012, 17, 1448-1467. [CrossRef]

31. Arya, V.P.; Enzell, C.; Erdtaman, H.; Kubota, T. Communic acid, a new diterpene acid from Juniperus communis L. Acta Chem. Scand. 1961, 15, 225-226. [CrossRef]

32. Lee, G.H.; Lin, C.C.; Cheng, Y.S.; Peng, S.M. Structure of methyl trans-communate. Acta Crystallogr. 1987, C43, 1382-1384.

33. Wu, Y.B.; Ni, Z.Y.; Shi, Q.W.; Dong, M.; Kiyota, H.; Gu, Y.C.; Cong, B. Constituents from Salvia species and their biological activities. Chem. Rev. 2012, 112, 5967-6026. [CrossRef] [PubMed]

34. Habibi, Z.; Eftekhar, F.; Samiee, K.; Rustaiyan, A. Structure and antibacterial activity of a new labdane diterpenoid from Salvia leriaefolia. J. Nat. Prod. 2000, 63, 270-271. [CrossRef] [PubMed]

35. Jassbi, A.R.; Eghtesadi, F.; Hazeri, N.; Ma'sumi, H.; Valizadeh, J.; Chandran, J.N.; Schneider, B.; Baldwin, I.T. The roots of Salvia rhytidea: A rich source of biologically active diterpenoids. Nat. Prod. Res. 2017, 31, 477-481. [CrossRef] [PubMed] 
36. Moridi Farimani, M.; Miran, M. Labdane diterpenoids from Salvia reuterana. Phytochemistry 2014, 108, 264-269. [CrossRef]

37. Shpatov, A.V.; Popov, S.A.; Salnikova, O.I.; Khokhrina, E.A.; Shmidt, E.N.; Um, B.H. Low-volatile lipophilic compounds in needles, defoliated twigs, and outer bark of Pinus thunbergii. Nat. Prod. Commun. 2013, 8, 1759-1762. [CrossRef]

38. Lin, T.C.; Fang, J.M.; Cheng, Y.S. Terpenes and lignans from leaves of Chamaecyparis formosensis. Phytochemistry 1999, 51, 793-801. [CrossRef]

39. Kitajima, J.; Noda, N.; Ida, Y.; Komori, T.; Kawasaki, T. Studies on the constituents of the crude drug "Fritillariae bulbus." IV. On the diterpenoid constituents of the crude drug "Fritillariae bulbus.". Chem. Pharm. Bull. 1982, 30, 3922-3931. [CrossRef]

40. Poulin, J.; Helwig, K. Inside amber: New insights into the macromolecular structure of Class Ib resinite. Org. Geochem. 2015, 86, 94-106. [CrossRef]

41. Lago, J.H.G.; Brochini, C.B.; Roque, N.F. Terpenes from leaves of Guarea macrophylla (Meliaceae). Phytochemistry 2000, 55, 727-731. [CrossRef]

42. Rather, M.A.; Hassan, T. Analysis of the diterpene rich essential oil of Nepeta clarkei hooke. from Kashmir himalayas by capillary GC-MS. Int. J. ChemTech Res. 2011, 3, 959-962.

43. Zhao, J.; Zhu, H.J.; Zhou, X.J.; Yang, T.H.; Wang, Y.Y.; Su, J.; Li, Y.; Cheng, Y.X. Diterpenoids from the feces of Trogopterus xanthipes. J. Nat. Prod. 2010, 73, 865-869. [CrossRef]

44. Bao, Y.; Wang, W.; Wu, H.; Qi, M.; Li, J.; Yang, Y. A new sesquiterpene from the barks of Manglietia hookeri. Nat. Prod. Res. 2016, 30, 2396-2401. [CrossRef]

45. Koroch, A.R.; Simon, J.E.; Juliani, H.R. Essential oil composition of purple basils, their reverted green varieties (Ocimum basilicum) and their associated biological activity. Ind. Crops Prod. 2017, 107, 526-530. [CrossRef]

46. Aydoğmuş, Z.; Yeşilyurt, V.; Topcu, G. Constituents of Salvia microphylla. Nat. Prod. Res. 2006, 20 , 775-781. [CrossRef]

47. Archile, B.O.K.; Mathieu, T.; Alembert, T.T.; Pierre, T.; Michel, F. eacute d eacute rich Terpenoids from Phaulopsis imbricata (Acanthaceae). J. Med. Plants Res. 2016, 10, 122-129. [CrossRef]

48. Ulubelen, A.; Öztürk, S.; Iśildatici, S. A new flavone from Salvia triloba L.f (Labiatae). J. Pharm. Sci. 1968, 57, 1037-1038. [CrossRef]

49. Lehbili, M.; Alabdul Magid, A.; Kabouche, A.; Voutquenne-Nazabadioko, L.; Abedini, A.; Morjani, H.; Gangloff, S.C.; Kabouche, Z. Antibacterial, antioxidant and cytotoxic activities of triterpenes and flavonoids from the aerial parts of Salvia barrelieri Etl. Nat. Prod. Res. 2018, 32, 2683-2691. [CrossRef]

50. Hasan, M.R.; Al-Jaber, H.I.; Al-Qudah, M.A.; Abu Zarga, M.H. New sesterterpenoids and other constituents from Salvia Dominica growing wild in Jordan. Phytochem. Lett. 2016, 16, 12-17. [CrossRef]

51. Srivedavyasasri, R.; Hayes, T.; Ross, S.A. Phytochemical and biological evaluation of Salvia apiana. Nat. Prod. Res. 2017, 31, 2058-2061. [CrossRef]

52. Mofidi Tabatabaei, S.; Salehi, P.; Moridi Farimani, M.; Neuburger, M.; De Mieri, M.; Hamburger, M.; Nejad-Ebrahimi, S. A nor-diterpene from Salvia sahendica leaves. Nat. Prod. Res. 2017, 31, 1758-1765. [CrossRef]

53. Mansourabadi, A.H.; Sadeghi, H.M.; Razavi, N.; Rezvani, E. Anti-inflammatory and Analgesic Properties of Salvigenin, Salvia officinalis Flavonoid Extracted. Adv. Herb. Med. 2015, 1, 31-41.

54. Singh, N.; Mahmood, U.; Kaul, V.K.; Jirovetz, L. A new phthalic acid ester from Ajuga bracteosa. Nat. Prod. Res. 2006, 20, 593-597. [CrossRef]

55. Pan, Y.P.; Ye, J.; Zhang, Y.; Jin, H.Z. Chemical Constituents of Hedyotis uncinella. Chem. Nat. Compd. 2017, 53, 738-739. [CrossRef]

56. Sivajothi, V.; Shruthi, S.D. In vitro and in silico anti-diabetic activity of phthalic acid isolated from phyllanthus rheedii. Int. J. Res. Ayurveda Pharm. 2013, 4, 889-892. [CrossRef]

57. Wahidulla, S.; D'Souza, L.; Govenker, M. Lipid constituents of the red alga Acantophora spicifera. Phytochemistry 1998, 48, 1203-1206. [CrossRef]

58. Bai, R.; Ma, F.; Liang, D.; Zhao, X. Phthalic acid induces oxidative stress and alters the activity of some antioxidant enzymes in roots of Malus prunifolia. J. Chem. Ecol. 2009, 35, 488-494. [CrossRef]

59. Dorney, J.R.; Weber, J.B.; Overcash, M.R.; Strek, H.J. Plant Uptake and Soil Retention of Phthalic Acid Applied to Norfolk Sandy Loam. J. Agric. Food Chem. 1985, 33, 398-403. [CrossRef] 
60. Chen, J.J.; Wu, H.M.; Peng, C.F.; Chen, I.S.; Chu, S. Der seco-Abietane diterpenoids, a phenylethanoid derivative, and antitubercular constituents from Callicarpa pilosissima. J. Nat. Prod. 2009, 72, 223-228. [CrossRef]

61. Ding, L.J.; Yuan, W.; Li, Y.X.; Liao, X.J.; Sun, H.; Peng, Q.; Han, B.N.; Lin, H.W.; Li, Z.Y.; Yang, F.; et al. Hypocrol A, a new tyrosol derivative from a sponge-derived strain of the fungus Hypocrea koningii. Nat. Prod. Res. 2016, 30, 1633-1638. [CrossRef]

62. Enzell, C.R.; Thomas, B.R. The chemistry of the Order Araucariales 3. Structure and configuration of araucarolone and some related compounds from Agathis australis. Acta Chem. Scand. 1965, 19, 1875-1896. [CrossRef]

63. Rivera-Chávez, J.; Zacatenco-Abarca, J.; Morales-Jiménez, J.; Martínez-Aviña, B.; Hernández-Ortega, S.; Aguilar-Ramírez, E. Cuautepestalorin, a 7,8-Dihydrochromene-Oxoisochromane Adduct Bearing a Hexacyclic Scaffold from Pestalotiopsis sp. IQ-011. Org. Lett. 2019, 21, 3558-3562. [CrossRef]

64. Bruhn, T.; Schaumlöffel, A.; Hemberger, Y.; Bringmann, G. SpecDis: Quantifying the comparison of calculated and experimental electronic Circular Dichroism spectra. Quirality 2013, 4325, 243-249. [CrossRef]

65. Rivera-Chávez, J.; Figueroa, M.; González, M.D.C.; Glenn, A.E.; Mata, R. $\alpha$-Glucosidase Inhibitors from a Xylaria feejeensis Associated with Hintonia latiflora. J. Nat. Prod. 2015, 78, 730-735. [CrossRef]

66. Sheldrick, G.M. Crystal structure refinement with SHELXL. Acta Crystallogr. Sect. C Struct. Chem. 2015, 71, 3-8. [CrossRef]

67. Spek, A.L. Structure validation in chemical crystallography. Acta Crystallogr. Sect. D Biol. Crystallogr. 2009, 65, 148-155. [CrossRef]

68. Cremer, D.; Pople, J.A. A General Definition of Ring Puckering Coordinates. J. Am. Chem. Soc. 1975, 97, 1354-1358. [CrossRef]

69. Carlson, R.P.; Lynn, O.D.; Chang, J.; Lewis, A.J. Modulation of mouse ear edema by cyclooxygenase and lipoxygenase inhibitors and other pharmacologic agents. Agents Actions 1985, 17, 197-204. [CrossRef]

70. Zhou, T.; Zhang, S.W.; Liu, S.S.; Cong, H.J.; Xuan, L.J. Daphnodorin dimers from Edgeworthia chrysantha with $\alpha$-glucosidase inhibitory activity. Phytochem. Lett. 2010, 3, 242-247. [CrossRef]

71. Ye, X.P.; Song, C.Q.; Yuan, P.; Mao, R.G. $\alpha$-Glucosidase and $\alpha$-Amylase Inhibitory Activity of Common Constituents from Traditional Chinese Medicine Used for Diabetes Mellitus. Chin. J. Nat. Med. 2010, 8, 349-352. [CrossRef]

72. Jo, S.H.; Ka, E.H.; Lee, H.S.; Apostolidis, E.; Jang, H.D.; Kwon, Y.I. Comparison of antioxidant potential and rat intestinal $\alpha$-glucosidases inhibitory activities of quercetin, rutin, and isoquercetin. Int. J. Appl. Res. Nat. Prod. 2009, 2, 52-60.

Sample Availability: Samples of the compounds are not available from the authors.

(C) 2020 by the authors. Licensee MDPI, Basel, Switzerland. This article is an open access article distributed under the terms and conditions of the Creative Commons Attribution (CC BY) license (http://creativecommons.org/licenses/by/4.0/). 